\section{Isiaq O. Oseni}

Department of Economics Faculty of Social Sciences Olabisi Onabanjo University Ago-Iwoye, Ogun State, Nigeria osenioou@yahoo.com

\section{Mumeen O. Alabi}

Department of Economics Faculty of Social Sciences Olabisi Onabanjo University, Ago-Iwoye, Ogun State, Nigeria alabimumeen9@gmail.com

\author{
Ibrahim A. Adekunle \\ (iD) https://orcid.org/0000-0001-9007-0296 \\ Department of Economics \\ Faculty of Social Sciences \\ Olabisi Onabanjo University \\ Ago-Iwoye, Ogun State, Nigeria \\ adekunle_ia@yahoo.com
}

\title{
Exchange rate volatility and industrial output growth in Nigeria
}

Accepted by Editor Ewa Ziemba | Received: March 1, 2019 | Revised: May 28, 2019; June 23, 2019 | Accepted: July 9, 2019.

\begin{abstract}
Aim/purpose - This paper examines the relationship between exchange rate volatility and industrial output growth in Nigeria. In spite of the massive revenue emanating from oil wealth, Nigeria has wallowed in intergenerational poverty due to the inability to grow its industrial sector. The dilemma of exchange rate allowed growth of the industrial sector to become enormous. As such, this paper attempts a quantitative analysis of industrial output growth in Nigeria as predicted by an exchange rate volatility using a time series data from the exchange rate and the industry value added from 1986 through 2017.

Design/methodology/approach - This paper adopts a quantitative analysis of exchange rate volatility as a predictor of changes in industrial output in Nigeria. Monthly Data on exchange rate from 1986 through 2017 were first analysed to show for their clustering behaviour. Thus, ascertaining whether they are volatile or not. The study employs $\operatorname{AR}(k)-\operatorname{EGARCH}(p, q)$ models for the calculation of volatility in the growth rate of nominal exchange rates. Then the paper adopts the Auto-Regressive Distributed Lag Approach to account for the long-run and short-run dynamics of industrial output in Nigeria as induced by volatility in the exchange rate for different regimes under the scope.
\end{abstract}

Cite as: Oseni, I. O., Adekunle, I. A., \& Alabi, M. O. (2019). Exchange rate volatility and industrial output growth in Nigeria. Journal of Economics \& Management, 38(4), 129-156. https://doi.org/10.22367/jem.2019.38.07 
Findings - The findings reveal that the real exchange rate volatility determines industrial production as well as availability of foreign exchange increments arising from the various export drives contributing tremendously to the increase in the industrial output in Nigeria. It is further revealed that the capacity utilisation ratio was low.

Research implications/limitations - Established evidence of low capacity utilisation may be due to the epileptic power supply, inadequate technological know-how. As such, the government should maintain a flexible exchange rate system to maximally harness the benefits of growth emanating from the industrial sector.

Originality/value/contribution - The paper specifically offers an experimental proof to the underlying relationship between industrial output and exchange rate volatility in Nigeria. Previous studies reviewed in the literature have mostly focused on the growth effect of the exchange rate neglecting the important nexus it shares with the industrial sector (a bedrock of sustainable development).

Keywords: Exchange Rate Volatility, industrial output, GARCH, ARDL, Nigeria. JEL Classification: C32, F43.

\section{Introduction}

The magnitude of the effect of the exchange rate policy adopted in contemporary ages has heightened the discourse on the subject matter. Donors, financial institutions, international organisations, industrial and labour organisations and the society at large are increasingly concerned about the rising disparities in local currency valuation to foreign currency. The resultant effects of a high exchange rate are enormous. The contraction in industrial output, prevalence of economic hardship, among other factors for a country that is extensively import dependent are few of the menace when the exchange rate is not correctly managed. No state exists in autarky; as such trade interactions become pertinent. The value to which one country exchanges its currency for the other has far more reaching implications. It determines their financial capacity regarding purchasing power parity on the international market. It defines the ability to attract foreign direct investment through conventional approaches to the cost-benefit analysis of investment opportunities. It also determines the value of export of country's goods and services as well as the nation's ability to import adequate technological know-how needed to propel the economy for better productivity.

However, the literature on exchange rate volatility and output growth has grown tremendously with divergent opinions on its growth effect, but its impact, particularly on industrial output growth, remains grossly understudied in Nigeria. Nwosu (2016), Ismaila (2016), Adeniran, Yusuf, \& Adeyemi (2014), Danmola (2013), and Adelowokan (2012) all concentrated on the aggregate 
growth pattern of the exchange rate, while only a few have examined the paradox of an industrial growth pattern inherent in contemporary exchange rate volatility in Nigeria. Most studies on the exchange rate in Nigeria (Adekoya \& Fagbohun, 2016; Lawal, 2016; Enekwe, Ordu, \& Nwoha, 2013) are channelled towards manufacturing a sector growth neglecting the primary sector and the service sector as another component of the industrial sector. This study examines the underlying drivers of industrial output growth in a conventional volatile exchange rate environment. The forward and backward linkage characteristics of the primary and service sector are essential for the growth of private consumptions (Oseni, 2016). This study comes in to complement the available literature on the volatile exchange rate-industrial output nexus in Nigeria and to address the anecdotal evidences provided by previous studies in the extant literature.

The impact of exchange rate volatility on output growth has been extensively studied mainly with regard to the international trade since late 1970 when the exchange rate moved from a fixed to a flexible system. The Marshal-Lerner condition argues that for devaluation to correct the balance of payment disequilibrium, the elasticity of import and export must be greater than one (1) (Bahmani-Oskooee \& Ratha, 2004). The Marshal-Lerner condition argues that higher exchange rate fluctuations impede trade thus resulting in risk and uncertainty that deter investor's confidence. Appropriate handling of the forward markets and proper management of the timings of payments and receipts can revive the exports and thus reduce the risks of investors in the short term. In the long run, exchange rate volatility may affect trade indirectly by influencing firms' investment decisions. How this assertion has played out for an overly importdependent nation like Nigeria remains unclear.

However, less restrictive models of the equilibrium exchange rate, such as the conventional Mundell-Fleming model (Mundell, 1963) or the generalised portfolio balance of Branson \& Buiter (1982) hypothesise that outcomes are not fixed for every level of full employment. It then postulates that the output growth significantly predicts the equilibrium exchange rate in the country. Hence, the real exchange rate which was usually assumed to be constant is highly correlated with the corresponding output levels. The reality of these hypothetical situations is that the real exchange rate should be co-integrated with the comparable levels of domestic industrial output. Scholars such as Oseni (2016), Ilechukwu \& Nwokoye (2015), Jongbo (2014), Muhammad, Streissle, \& Kunst (2012); Khondker, Bidisha, \& Razzaque (2012), among others, are of the opinion that favourable exchange rate causes sectoral growth and subsequently economic growth, whiles Addae \& Ackah (2017) and Sattar \& ur Rehman (2012) 
argue that an output growth causes an exchange rate appreciation. The inconclusiveness of the theoretical positions, as well as the divide in the extant literature, needs further verification to ascertain the direction of causality that exists between an exchange rate volatility and an industrial output growth in Nigeria. This backdrop forms the justification for this paper to unravel the effect of exchange rate volatility on industrial output growth in Nigeria. It also aims at establishing the direction of causality that exists between industrial output growth and exchange rate volatility in Nigeria during the period of investigation.

Having introduced the study, the subsequent section gives the literature review, section three discusses the methodology, section four shows the presentation and the analysis of the result while the last section offers the summary and the conclusion to the study.

\section{Literature review}

\subsection{Theoretical framework}

The argument that the elimination of the exchange risk will lead to an increase in economic growth can be made using the neoclassical growth model, and its extension to situations of dynamic economies of scale. According to this model, elimination of exchange risk reduces the systemic risk (Ito, Koibuchi, Sato, \& Shimizu, 2016). This would have the effect of lowering the real interest rate (Franke, 1991). The reason is that in a less risky environment, investors would require a lower risk premium to make the same investment. Besides, when agents discount the future, they are willing to use a smaller discount rate. Due to this, there will be an accumulation of a capital and an increase in the growth rate of an industrial output. Some of the various channels through which exchange rate volatility transmits to more industrial output growth and subsequently economic growth are described below.

\section{Trade}

The correlation between exchange rate volatility and international trade is highly explored and well established. According to Brodsky (1984), due to a risk-averse (or even risk-neutral) behaviour of commodity traders, a higher exchange rate uncertainty may lead to a reduction in the volume of trade. The main idea is the demand for a higher price by economic agents to cover their 
exposure to currency risk. In turn, it would decrease the volume of trade. Other than the direct effect of an exchange rate volatility on trade, there may be a more or less important indirect effect of an exchange rate volatility on trade and hence on an industrial output growth.

\section{Foreign direct investment}

Exchange rate volatility may also affect the level of development of the country through its effects on foreign direct investment inflows. The main idea is that the higher exchange rate volatility increases uncertainty over the return on the investment (Kiyota \& Urata, 2004). A potential investor will invest in a foreign location only if the expected returns are high enough to cover the currency risks. Thus, under high exchange rate volatility, the foreign direct investment will be lower. This can be counted as another channel through which unfavourable impact of exchange rate volatility on the growth of the industrial sector and subsequently economic growth can be traced out.

\section{Currency crises}

It is argued that instability in prominent currencies can contribute to currency crises in small countries (Coudert, Couharde, \& Mignon, 2011). The idea behind this is if a big currency (dollar) had significant and relatively rapid appreciation vis-à-vis other prominent currencies (i.e. euro, yen) then all the currencies that were pegged to the dollar also appreciated, concerning euro and yen. The result is the weakening of relative price competitiveness of these currencies, thus contributing to a deterioration of their external accounts and may eventually have led to the currency crises. Therefore, exchange rate volatility is not the volatility itself, but a continuous change of one currency in a specific direction adversely affecting the real economy.

\section{Debt servicing costs}

One of the main effects of exchange rate movements for developing countries refers to the external debt burden (Edwards \& Rigobon, 2009). As most of the developing countries are net debtors, hence changes in exchange rates may affect the real cost of servicing their debts. A sharp appreciation of the dollar, for example, implies a higher cost of servicing an external obligation. Thus, high exchange rate fluctuations affect the allocation of funds for a development purpose. 


\section{The distinction between exchange-rate volatility and appreciations/depreciations}

Probably the most important characteristic of alternative exchange rate systems is the feature used to describe them, namely fixed or floating. Fixed exchange rates, by definition, are not supposed to change. They are meant to remain fixed for, ideally, a permanent period of time. Floating rates, do just that, they float up and down, down and up, from year to year, week to week, and by the minute. What a floating exchange rate will be a year from now, or even a week from now, is often very difficult to predict.

Volatility represents the degree to which a variable changes over time. The larger the magnitude of a variable change, or the more quickly it changes over time, the more volatile it is (Gray \& Irwin, 2003). Since fixed exchange rates are not supposed to change, they have no volatility. However, it is worthy to note that this should cautiously be worded because fixed exchange rates are quite frequently devalued or revalued, implying that they can and do indeed change (Obstfeld \& Rogoff, 2011). A floating exchange rate may or may not be volatile depending on how much it changes over time. However, since floating exchange rates are free to change, they are generally expected to be more volatile (Calvo \& Reinhart, 2002; MacDonald, 2007; Klein \& Shambaugh, 2008).

Volatile exchange rates make an international trade and investment decisions more difficult because volatility increases an exchange rate risk (Devereux \& Engel, 2002; Sensoy \& Sobaci, 2014). An exchange rate risk refers to the potential to lose money because of a change in the exchange rate. It has a significant bearing of the magnitude of a change and direction for an industrial output for traders and investors. Nonetheless, exchange rate fluctuations show the degree to which the exchange rate changes over time. However, the speed of changes in exchange rate fluctuations is not comparable to what is obtainable in a volatile exchange rate environment majorly because of the frequency of changes that are recorded (Baron, 1976).

\subsection{Empirical review}

The literature on the exchange rate and growth outcome has grown over the years, but its impact on industrial output growth remains grossly understudied, particularly in Nigeria. The study presents evidence of empirical debates in the literature of an exchange rate volatility in Nigeria in a chronological order for an ease of appreciation. 
Englama, Duke, Ogunleye, \& Isma'il (2010) empirically examined oil prices and an exchange rate volatility in Nigeria using monthly data for the period 1999:1 to 2009:12. The authors utilise a co-integration technique and the vector error correction model (VECM) for the long-run and the short-run analysis, respectively. The authors found a one (1) per cent permanent increase in oil price at the international market increases exchange rate volatility by 0.54 per cent in the long-run, while in the short-run by 0.02 per cent. This study deviates from the from the conventional approach that is sorted out in this study.

Essien, Dominic, \& Sunday (2011) examined the effects of price and exchange rate fluctuations on agricultural exports in Nigeria. An export supply function for cocoa was specified and estimated using the Ordinary Least Squares Regression. Results showed that exchange rate fluctuations and agricultural credits positively affect cocoa exports in Nigeria. Their econometric analysis is faulty as they explained the relationship between the variables of interest using Ordinary least square regression despite reporting variables of order of integration that are stationary at first difference.

Adeoye \& Atanda (2011) examined the consistency, persistency and severity analyses of an exchange rate volatility in Nigeria vis-à-vis the United States dollar using monthly a time series data from 1986 to 2008. The standard Purchasing Power Parity (PPP) model was used to analyse the long-run consistency of the naira exchange rate, while the time series properties of the data were examined using the Augmented Dickey Fuller (ADF) and the Philip Peron (PP) approach, the stationary process, and an order of the incorporated series. The $\mathrm{ARCH}$ and GARCH models were used to examine the degree or severity of volatility based on the first difference, standard deviation and coefficient of deviation estimated volatility series for the nominal and real exchange rate of naira vis-à-vis the U.S dollar. The result indicated the presence of overshooting volatility shocks. The econometric analyses further revealed that the nominal and real exchange rates of naira vis-à-vis the U.S. dollar are not with the traditional long-run PPP model. All the incorporated measures of volatility indicated presence and persistency of volatility in the nominal and real exchange rate for the naira vis-à-vis the U.S. dollar in Nigeria. However, the study measures of volatility do not explain its implications for industrial output growth in Nigeria.

Ismaila (2016) examined an exchange rate depreciation and economic growth of Nigeria during the SAP (Structural Adjustment Programme) and postSAP period using the Johansen co-integration test and the error correction model analyses. The findings reveal that a broad money supply, a net export, and a total government expenditure have a significant impact on outcomes of a real output 
in the long-run. Moreover, the exchange rate has a linear but insignificant effect on economic growth in Nigeria in the short and long term. The implications are that exchange rate depreciation during the SAP period has no significant impact on Nigeria's financial performance.

Abdul-Mumuni (2016) examined the effect of an exchange rate variability on a manufacturing sector performance in Ghana. The author used the AutoRegressive Distributed Lag model to analyse time series data and found that there exists a short- and long-run relationship between an exchange rate and a manufacturing sector performance. Thus, in Ghana, as the exchange rate appreciates, the manufacturing sector performance improves, and as it depreciates, the sector is adversely affected.

Lawal (2016) examined the effect of exchange rate fluctuations on the manufacturing sector output in Nigeria from 1986 to 2014. The study adopts Auto-Regressive Distribution Lag (ARDL) to investigate the impact of exchange rate fluctuations on the manufacturing sector. Results discovered that exchange rate fluctuations have a long- and short-run correlation with a manufacturing sector output. The result showed that the exchange rate has a positive but not significant correlation with a manufacturing sector output. However, findings also revealed that the exchange rate is positively related to a manufacturing sector output in Nigeria. Ilechukwu \& Nwokoye (2015) adopted the Ordinary Least Square (OLS) technique to examine the impact of exchange rate stability on industry output in Nigeria. The study used annual time series data from 1980 to 2013 and found that the explanatory variables (a domestic capital, a foreign direct investment, a population growth rate, and a real exchange rate) influence an industrial output in Nigeria. The variability in external balance and inflation does not affect an industrial output in Nigeria.

Adeniran et al. (2014) investigated the effect of an exchange rate on the economic growth in Nigeria from 1986 to 2013 using the Ordinary Least Square (OLS). The authors found that the exchange rate has a positive but not significant relationship with an economic growth. The channels through which an exchange rate volatility induces growth or the otherwise in an industry value addition was not clear.

Jongbo (2014) examined the impact of real exchange rate fluctuation on industrial output using OLS. The results show that the real exchange rate plays a significant role in determining the industrial output in Nigeria. Exchange rate fluctuations (appreciation/depreciation) differ in magnitude and influence to volatility in exchange rate, and as such worst scenarios are expected for the growth or otherwise of industrial productions in a volatile exchange rate environment. 
Mensah, Awunyo-Vitor, \& Asare-Menako (2013) examined how an employment growth in the Ghanaian manufacturing sector is affected by the fluctuating exchange rate using Ordinary Least Squares (OLS) regression technique. Findings revealed that an exchange rate volatility significantly impacts on an employment growth in the manufacturing sector firms in Ghana. Thus, the devaluation of the Ghanaian cedi against the U.S. dollar set the economic growth of Ghana on the back foot. Further revelations show that the interest rate is averse to employment growth in the manufacturing sector of Ghana, while Gross Domestic Product (GDP) shows a positive correlation with employment growth in Ghana. Through the prudent management of the exchange rate, can be seen a significant increase in the employment in the manufacturing sector. The authors have mistaken an exchange rate fluctuations measurement for an exchange rate volatility measurement which has made results emanating from their studies largely unfounded.

Danmola (2013) analysed the impact of an exchange rate volatility on macroeconomic variables using the Ordinary Least Square (OLS) and the Granger Causality test. The result of the analysis shows that exchange rate volatility has a positive correlation with the GDP, the Trade Openness, and the Foreign Direct Investment. Nevertheless, exchange rate volatility has a negative impact on the inflationary rate in the country. Muhammad et al. (2012) explored the impact of an exchange rate volatility on an industrial production before and after the introduction of a common currency for 11 European countries which constitute the European Monetary Union and for four European states that did not adopt the 'euro' as a common currency. The study employed monthly data of an exchange rate and macroeconomic variables from January 1980 to April 2009 for the analysis and used the AR(k)-EGARCH(p,q) models for calculation of a volatility in the growth rate of nominal and real exchange rates for all the countries before and after the introduction of universal currency separately. After adopting pooled IV (Instrumental variables)/TSLS (Two Stage Least Square), they conclude that all the nations enjoyed benefits after the introduction of a common currency by the reduction in adverse impacts of a real exchange rate volatility, even some countries also faced an increase in a real exchange rate volatility.

Adeniyi, Oyinlola, \& Omisakin (2011) examined the employment effect of the real exchange rate in Nigeria manufacturing sector between 1970 and 2008 using GARCH modelling. The result indicates that an exchange rate volatility has a significant positive impact on a manufacturing employment through orientation channels and an adverse effect through import orientation channels. 
Azid, Jamil, \& Kousar (2005) examined the impact of exchange rate volatility on growth and economic performance in Pakistan from 1973-2003. They found the exchange rate to be highly volatile but with a positive and significant effect on an output growth.

Okafor, Adegbite, \& Abiola (2018) investigated an exchange rate fluctuation, an inflation and an industrial output in Nigeria from 1981Q1 to 2015Q4. The study adopted the Structural Vector Autoregressive (SVAR) econometric technique to analyse the impact of a shock to the independent variables on an industry output. The study found that a positive shock to a exchange rate has a negative impact on an output growth and that a positive shock to an inflation has a temporal negative effect on an output and becomes positive after the fourth quarter. The forecast error variance decomposition technique showed that the exchange rate and an inflation account for about 2.6 percent and 10 percent of variations in an industry output, respectively.

Most of these studies have failed to examine the productive capacity of an industrial output growth in Nigeria considering the volatile exchange rate environment in Nigeria for the study period. Few surveys that came close to examining the relationship between a volatile exchange rate and its implications for growth in the industrial sector provide anecdotal evidences (Adeoye \& Atanda, 2008; Ogundipe, Ojeaga, \& Ogundipe, 2014; Okafor et al., 2018). This study also looks to resolve the methodological ambiguity in the extant literature of a volatile exchange rate and its implications for growth in the industrial sector in Nigeria. It is against this backdrop that this study seeks to unravel the structural relationship between exchange rate volatility and industrial output growth in Nigeria.

\section{Research methodology}

The empirical model for the study is based on the neoclassical growth model with the extension to the dynamic economies of a scale which expresses a relationship between a growth $(\mathrm{Y})$ as depending on a capital $(\mathrm{K})$ and a labour (L) in tandem with Solow (1956). There is only one commodity, output as a whole, whose a rate of production is designated $Y_{t}$. Part of each an instant's output is consumed and the rest is saved and invested. The fraction of saved output is a constant, consequently the rate of saving is $s Y_{t}$. The economy's stock of capital $K_{t}$ takes the form of an accumulation of the composite commodity produced. Net investment is then just the rate of increase of this capital stock $\delta K / \delta t$ or $K$, so we have the basic identity at every instant of time: 


$$
\dot{K}=s Y
$$

The output is produced with the help of two factors of a production, a capital and a labour, whose rate of input is $L_{t}$. Technological possibilities are represented by a production function:

$$
Y=f(K, L)
$$

In this study, we augment the neoclassical Solow growth model to explain an industrial output growth as induced by the volatility in the exchange rate. The functional form of the model is:

$$
I N D P=f\left(E X C_{R}, E X P, I M P, T R A_{O P E N}, F D I\right)
$$

where INDP represents industrial output growth proxy with industry value added, $E X C_{R}$ represents a exchange rate volatility measured as the conditional variance exchange rate level; $E X P$ denotes the a volume of exports of goods and services; IMP proxies' volume of import of goods; TRA OPEN represents Trade Openness, FDI captures Foreign Direct Investment.

\section{Restating the model in an econometric form:}

$$
\begin{gathered}
I N D P_{t}=\beta_{0}+\beta_{1} E X C_{R_{t}}+\beta_{2} E X P_{t}+\beta_{3} I M P_{t}+\beta_{4} T R A_{O P E N_{t}}+ \\
\beta_{5} F D I_{t}+\varepsilon_{t}
\end{gathered}
$$

where $\varepsilon_{t}$ represents an error term and $\beta_{1-5}$ are a parameter estimates of the model. These variables are log-linearised to adjust for disparities in units and measurements.

$$
\begin{aligned}
\ln I N D P_{t} & =\beta_{0}+\beta_{1} \ln E X C_{R_{t}}+\beta_{2} \ln E X P_{t}+\beta_{3} \operatorname{lnIMP} P_{t} \\
& +\beta_{4} \ln T R A_{\text {OPEN }_{t}}+\beta_{5} \ln F D I_{t}+\varepsilon_{t}
\end{aligned}
$$

\section{Data sources and measurements}

Our study used time series (monthly) data for an industrial output growth (measured with industry value added) and indicators for an exchange rate volatility in Nigeria (a nominal exchange rate, a value of imports of goods and services, a value of export of goods and services, a trade openness, an inflow of foreign direct investment) from 1986 through 2017. The data are mainly obtained from the CBN statistical bulletin various issues up until 2017 and World Bank Database (World Bank, 2017). 


\section{Estimation technique}

In accounting for the short-run and long-run dynamics of an exchange rate volatility and an industrial output growth in Nigeria, the study employs various econometric procedures. Firstly, the pre-estimation tests (descriptive statistics, correlation matrix) were conducted to ascertain the characteristics of the variables. Secondly, the monthly report of the exchange rate was used to establish the volatility or otherwise of the exchange rate in Nigeria.

Exchange rate volatility is measured as the conditional variance exchange rate level constructed from a monthly data. The conditional variance is the true measure of volatility about a variable given a model and an information set. To obtain the conditional variance of the exchange rate, the study uses GARCH (1, 1) specification as follows:

$$
\begin{aligned}
& E X_{t}=\emptyset_{0}+\sum_{i=1}^{n} \emptyset_{i} E X_{t-1}+\mu_{t} \\
& \sigma_{t}^{2}=\emptyset+\sum_{i=1}^{p} \vartheta_{i} \mu_{t-1}^{2}+\sum_{j-1}^{q} \varphi_{j}+\sigma_{t-1}^{2}
\end{aligned}
$$

Eq. (6) is the mean equation, where $E X_{t}$ is the exchange rate at time $t$, $E X_{t-1}$ is precursory to the previous exchange rate, and $\mu_{t}$ represents the white noise error term. In Eq. (7), $\sigma_{t}^{2}$ is the one-period-ahead forecast for the variance of an exchange rate based on past information or a volatility, $\sigma_{t-1}^{2}$ is the previous volatility (GARCH term), and $\mu_{t-1}^{2}$ denotes the last information about a volatility (ARCH term) while the equation is called the conditional variance equation. The GARCH $(1,1)$ equation above is used to generate the exchange rate volatility series for the yearly data set, and this is included in the time series data model in Eq. (3) above.

The a priori expectation of the explanatory variables in the model is expected to be:

$$
\beta_{2}, \beta_{4}, \beta_{5}>0 \text { while } \beta_{1}, \beta_{3}<0 \text {. }
$$

These expectations are based on economic theory that an increase in $F D I, E X P$, and $T R A_{O P E N}$ will lead to an increase in $I N D_{O u t}$, while an increase $E X C_{R}$, and IMP will lead to a decrease in $I N D_{O u t}$. 


\section{Research findings}

\subsection{Descriptive statistic and correlation matrix}

Table 1 shows that the mean and median values of the variables in the data set lie within the maximum and minimum values indicating a high tendency of the normal distribution. Industry value added, and value of export is positively skewed, while exchange rate, the value of import, trade openness and foreign direct investment are negatively skewed. The kurtosis statistics showed that industrial output growth, exchange rate, importation, trade openness and foreign direct investment were platykurtic, suggesting that their distributions were flat relative to a normal distribution. The Jarque-Bera statistics shows that the series is normally distributed since the p-values of all the series are not statistically significant at $5 \%$ level. Thus, informing the acceptance of the null hypothesis that says each variable is normally distributed.

Table 1. Descriptive statistics of the data set

\begin{tabular}{|c|c|c|c|c|c|c|}
\hline Description & $\ln I N D P$ & $\ln E X C_{R}$ & $\ln E X P$ & LnIMP & $\operatorname{lnTRA_{OPEN}}$ & $\ln F D I$ \\
\hline Mean & 23.994 & 3.857 & 23.870 & 23.467 & 13.834 & 21.428 \\
\hline Median & 23.585 & 4.712 & 23.780 & 23.499 & 14.090 & 21.351 \\
\hline Maximum & 25.666 & 5.260 & 25.699 & 25.205 & 16.404 & 22.903 \\
\hline Minimum & 22.371 & 0.562 & 21.738 & 21.491 & 10.218 & 19.079 \\
\hline Std. Dev. & 1.059 & 1.372 & 1.121 & 1.148 & 2.055 & 0.992 \\
\hline Skewness & 0.176 & -0.794 & 0.038 & -0.017 & -0.282 & -0.249 \\
\hline Kurtosis & 1.643 & 2.347 & 1.869 & 1.661 & 1.744 & 2.362 \\
\hline Jarque-Bera & 2.540 & 3.804 & 1.659 & 2.316 & 2.448 & 0.846 \\
\hline Probability & 0.281 & 0.149 & 0.436 & 0.314 & 0.294 & 0.655 \\
\hline
\end{tabular}

Source: Author's computation (2019).

Furthermore, studies (Hamsal, 2006 as cited in Oseni, 2016; Nugroho, 2012) have argued that testing of the correlation among the variables of estimates would cause the researchers to detect whether the variables have high multicollinearity among themselves. As a result, the parameter estimates may contradict what the theory says due to the unexpected effect of a multicollinearity among the independent. However, Iyoha (1977) argued that a multicollinearity among variables occurs when the result of the correlation coefficient is above 0.95. In line with this explanation, the study presents the results of the correlation analysis of the set of variables employed in Table 2 below. The table shows that the correlation coefficients among the variables of an industrial output 
growth, an exchange rate, an importation, a trade openness and a foreign direct investment are below 0.95 , indicating that there is no tendency for multicollinearity to occur among the independent variables.

Table 2. Correlation matrix of the data set

\begin{tabular}{|l|l|l|l|l|l|l|}
\hline \multicolumn{1}{|c|}{ Variable } & \multicolumn{1}{|c|}{$\boldsymbol{I N D P}$} & \multicolumn{1}{|c|}{$\boldsymbol{E X C _ { \boldsymbol { R } }}$} & \multicolumn{1}{c|}{$\boldsymbol{I M P}$} & \multicolumn{1}{|c|}{$\boldsymbol{E X P}$} & \multicolumn{1}{|c|}{$\boldsymbol{F D I}$} & TRA $_{\text {OPEN }_{\boldsymbol{t}}}$ \\
\hline INDP & 1 & & & & & \\
\hline EXC_R & -0.802 & 1 & & & & \\
\hline IMP & -0.841 & -0.821 & 1 & & & \\
\hline EXP & 0.837 & 0.771 & 0.844 & 1 & & \\
\hline FDI & 0.809 & -0.723 & 0.875 & 0.847 & 1 & \\
\hline TOP & 0.832 & 0.820 & 0.881 & 0.817 & 0.876 & 1 \\
\hline
\end{tabular}

Source: Author's computation (2019).

\subsection{ARCH effect and volatility clustering}

To test whether the monthly report of the exchange rate is volatile over the periods of study, the residual obtained from the exchange rate volatility model using the GARCH $(1,1)$ must satisfy two conditions. That is, it must have an $\mathrm{ARCH}$ effect, and the volatility must be clustered otherwise the variable is not volatile.

Table 3 indicates that the residual has the Auto-Regressive Conditional Heteroskedasticity (ARCH) effect since the F-statistic is statistically significant at $5 \%$ level, implying that we reject the null hypothesis that there is no ARCH effect and accept alternative hypothesis that there is ARCH effect.

Table 3. ARCH effect test result

\begin{tabular}{|l|l|l|l|}
\hline Heteroskedasticity Test: ARCH & \multicolumn{4}{l|}{} \\
\hline F-statistic & 0.0006 & Prob. F(1,367) & 0.012 \\
\hline Obs*R-squared & 0.0005 & Prob. Chi-Square(1) & 0.002 \\
\hline
\end{tabular}

Source: Author's computation (2019).

Figure 1 shows that the periods of high volatility are followed by the periods of high volatility for a prolonged period; also, the periods of low volatility are followed by the periods of low volatility for a prolonged period which revealed the graph of monthly report of exchange rate volatility cluster and as such volatile. 
Figure 1. Graph of monthly report of exchange rate volatility clustering

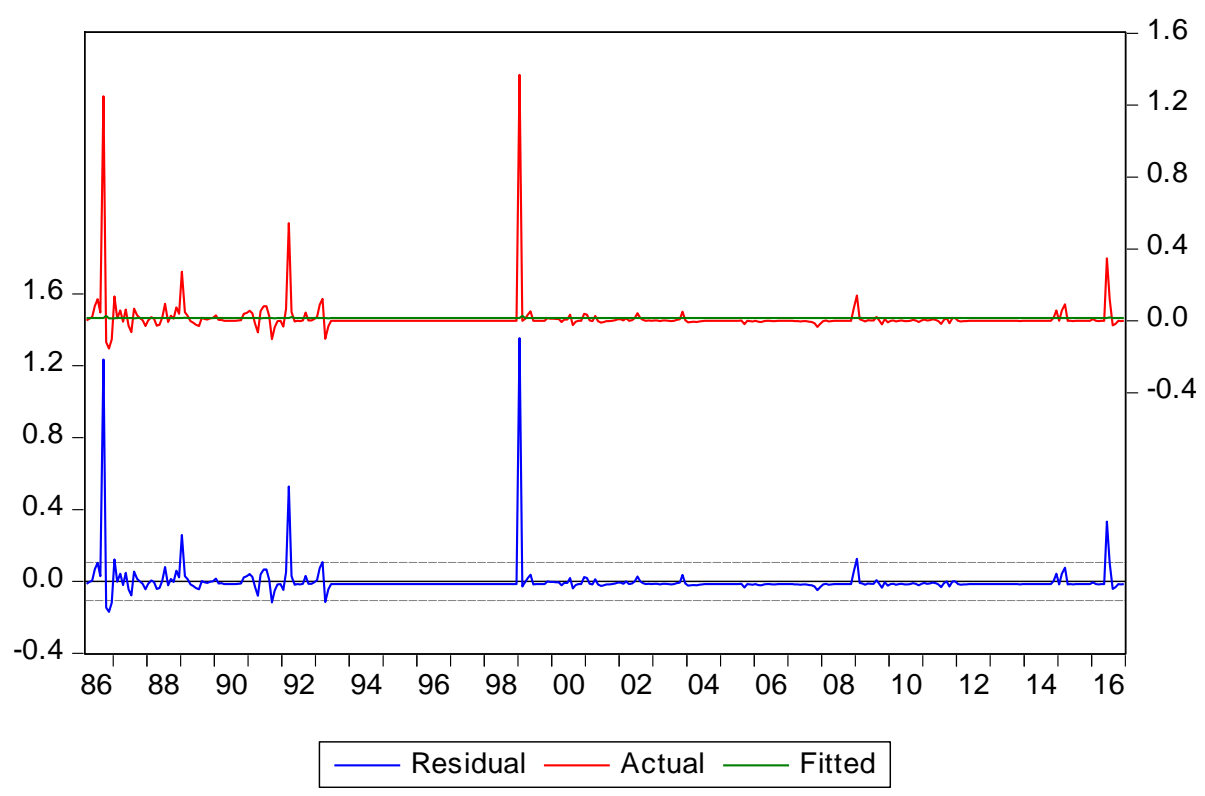

The coefficient of exchange rate volatility has a negative sign and statistical significance at $1 \%$ level. The indirect relationship exerts between an exchange rate volatility and an industrial output growth in Nigeria and shows that volatility in the exchange rate would result in a decrease in industry value added. This result implies that investor's confidence will be feeble which we drag an aggregate investment in the industrial sector to its minimum arising as a fear of a high level of uncertainty that threatens existing and potential investors continual profitability. Then, this action would lead to a fall in an aggregate investment and a subsequently industrial output growth.

\section{Time series properties of the variables}

The Augmented Dickey-Fuller (ADF) test is used to test for stationarity of the data (Table 4). The ADF test consists of estimating the following regression model:

$$
\Delta Y_{t}=\alpha+\beta_{\mathrm{t}}+\delta Y_{t-1}+\sum_{i=1}^{m} \varphi i \Delta Y_{t-i}+\varepsilon_{t}
$$

where $\alpha$ represents the drift, $t$ represents a deterministic trend and $m$ gives the maximum lag length large enough to ensure that $\varepsilon_{t}$ is a white noise error term. 
Table 4. Unit Root test: Augmented Dickey-Fuller test (ADF)

\begin{tabular}{|l|c|c|c|c|c|}
\hline \multicolumn{1}{|c|}{ Variables } & $\begin{array}{c}\text { Level } \\
\text { T-Stat }\end{array}$ & $\begin{array}{c}\text { Critical Value } \\
\text { @ 5\% }\end{array}$ & $\begin{array}{c}\text { First } \\
\text { Difference } \\
\text {-Stat }\end{array}$ & $\begin{array}{c}\text { Critical Value } \\
\text { @ 5\% }\end{array}$ & $\begin{array}{c}\text { Order of } \\
\text { Integration }\end{array}$ \\
\hline $\ln I N D_{P}$ & -1.305 & -4.546 & -4.899 & -2.972 & $\mathrm{I}(1)$ \\
\hline $\ln E X C_{R}$ & -3.026 & -6.423 & -5.592 & -2.968 & $\mathrm{I}(0)$ \\
\hline $\ln E X P$ & -1.553 & -4.284 & -7.221 & -2.543 & $\mathrm{I}(1)$ \\
\hline $\ln I M P$ & -1.238 & -2.964 & -5.780 & -2.729 & $\mathrm{I}(1)$ \\
\hline $\ln T R A_{\text {OPEN }}$ & -2.513 & -4.761 & -3.483 & -2.636 & $\mathrm{I}(1)$ \\
\hline $\ln F D I$ & -2.526 & -3.821 & -9.637 & -2.837 & $\mathrm{I}(1)$ \\
\hline
\end{tabular}

Source: Author's computation (2019).

The study used the Augmented Dickey-Fuller (ADF) to ascertain the order of integration of the variables. It is observed that log of the nominal exchange rate was stationary at level $\mathrm{I}(0)$ at $5 \%$ significance level, while the log of industry value added, the log of export, the log of import, the log of trade openness and the $\log$ of foreign direct investment are stationary at first difference at 5\% significance level. The appropriate modus operandi of analysis that captures the combination of $\mathrm{I}(1)$ and $\mathrm{I}(0)$ stationary variables is the Auto-Regressive Distributed Lag (ARDL) model (Pesaran Shin, \& Smith, 2001; Pesaran \& Shin, 2012). The functional relationship is given as:

$$
\begin{gathered}
\Delta I N D_{P_{t}}= \\
\alpha_{0}+\sum_{i=1}^{n} \alpha_{1 i} \Delta I N D_{P_{t-1}}+\sum_{i=1}^{n} \alpha_{2 i} \Delta E X C_{R_{t-1}}+\sum_{i-1}^{n} \alpha_{3 i} \Delta E X P_{t-1}+ \\
\sum_{i=1}^{n} \alpha_{4 i} \Delta I M P_{t-1}+\sum_{i=1}^{n} \alpha_{5 i} \Delta T R A_{O P E N_{t-1}}+\sum_{i=1}^{n} \alpha_{6 i} \Delta F D I_{t-1}+ \\
\beta_{1} I N D_{P_{t-1}}+\beta_{2} E X C_{R_{t-1}}+\beta_{3} E X P_{t-1}+\beta_{4} I M P_{t-1}+\beta_{5} T R A_{O P E N} t-1 \\
\beta_{6} F D I_{t-1}+\mu_{t}
\end{gathered}
$$

where $\Delta$ is the first difference operator, $\alpha_{0}$ is the drift component, $\mu_{\mathrm{t}}$ is the white noise error term.

The equation above connotes the term with the summation sign and represents the error correction dynamics, i.e. $\alpha_{1}-\alpha_{6}$, while the second part $\beta_{1}-\beta_{6}$ represents the long-run relationship. Accounting for the short-term relationship, the primary form becomes:

$$
\begin{aligned}
& \Delta I N D_{P_{t}}= \\
& \alpha_{0}+\sum_{i=1}^{n} \alpha_{1 i} \Delta I N D_{P_{t-1}}+\sum_{i=1}^{n} \alpha_{2 i} E X C_{R_{t-1}}+\sum_{i-1}^{n} \alpha_{3 i} \Delta E X P_{t-1}+ \\
& \sum_{i=1}^{n} \alpha_{4 i} \Delta I M P_{t-1}+\sum_{i=1}^{n} \alpha_{5 i} \Delta T R A_{O P E N} t-1 \\
& \varepsilon_{t}
\end{aligned}
$$

where $E C T$ is the error correction term which is the residuals retrieved from the estimated long-run relationship. 


\section{Lag length selection}

The issue of finding the appropriate lag length for each of the underlying variables in the ARDL model is fundamental because we want to have the Gaussian error terms. In selecting the optimal lag length for the co-integration equation based on the hypothesis that the residuals are serially uncorrelated, the lag length value that minimises the Schwarz Criterion (SC) and at which the model does not have autocorrelation is the optimal lag length. We proceed to test the Schwarz Criterion (SC) information criterion and the result is as follows:

Table 5. Lag length selection

\begin{tabular}{|c|c|}
\hline Lag length & SC \\
\hline 1 & $2.743^{*}$ \\
\hline 2 & 4.900 \\
\hline 3 & 6.423 \\
\hline
\end{tabular}

* Denotes the optimal lag length with the lowest information criteria.

Source: Author's computation (2019).

Based on the result in Table 5, the lag length which minimises SC is lag one and thus our optimal lag length. Given our optimal lag length, we proceed to test for the long-run relationship between the variables.

The estimation of the optimal lag length is based on the short run and long run ARDL model estimated.

\section{The bound test approach}

To investigate the presence of long-run relationships among the variables, the bound testing under Pesaran et al. (2001) procedure is used. The bound testing procedure is based on the F-test. The F-test is a test of the assumption of no co-integration among the variables against the premise of its existence, denoted as: $H_{0}: \beta_{1}=\beta_{2}=\beta_{3}=\beta_{4}=\beta_{5}=\beta_{6}=0$, i.e. there is no co-integration among the variables. This hypothetical representation is based on the specified ARDL model in equations 9 and 10 $H_{1}: \beta_{1} \neq \beta_{2} \neq \beta_{3} \neq \beta_{4} \neq \beta_{5} \neq \beta_{6} \neq 0$, i.e. there is co-integration among the variables. 
Given the result of the bound test, the F-statistic value should be compared with the Pesaran critical value at traditional levels of significance. It is noted by Narayan (2005), the current critical values reported in Pesaran et al. (2001) cannot be used for small sample sizes because they are predicated on the premise of the existence of large sample sizes. Narayan (2005) provided a set of critical values for sample sizes ranging from 30 to 80 observations. They are 2.4962.346 at $10 \%$ level of significance, 2.962-3.910 at 5\% level of significance and 4.068-5.250 at $1 \%$ level of significance.

Since the F-statistic 5.463445 (Table 6) is lower than the lower bound critical value, we thus reject the null hypothesis and conclude that an industrial output growth, a foreign direct investment, a gross capital formation, a trade openness, an exchange rate, and a cost of capital have co-movements in the long-run in Nigeria. From the result, we can hence estimate the long-run relationship between industrial output growth and the explanatory variables.

Table 6. Bound test result

\begin{tabular}{|l|c|c|c|c|c|c|}
\hline F-statistic & \multicolumn{2}{|c|}{$1 \%$} & \multicolumn{2}{c|}{$5 \%$} & \multicolumn{2}{c|}{$10 \%$} \\
\hline \multirow{3}{*}{5.463} & $\begin{array}{c}\text { Lower } \\
\text { bound }\end{array}$ & $\begin{array}{c}\text { Upper } \\
\text { bound }\end{array}$ & $\begin{array}{c}\text { Lower } \\
\text { bound }\end{array}$ & $\begin{array}{c}\text { Upper } \\
\text { bound }\end{array}$ & $\begin{array}{c}\text { Lower } \\
\text { bound }\end{array}$ & $\begin{array}{c}\text { Upper } \\
\text { bound }\end{array}$ \\
\cline { 2 - 7 } & 3.41 & 4.68 & 2.62 & 3.79 & 2.26 & 3.35 \\
\hline
\end{tabular}

Source: Author's computation (2019).

The results indicate that in the long-run, as an industrial output increases, the value of export, a foreign direct investment, and a trade openness also increase, while an industrial output decreases with the exchange rate, and a value of import increments (Table 7). However, the t-statistics showed the only significance for the exchange rate, the value of export (at 1\%), a trade openness and an import (only negative coefficient) at the $5 \%$ p-value. The result of the foreign direct investment was not significant and hence no significant change in its impact on output growth. The adjusted R-square shows that the explanatory variables of the model explain $87.5 \%$ variation in the dependent variable (industry value added) in the long-run, while the remaining $12.5 \%$ was not captured endogenously. The value of the F-statistic was statistically significant at $1 \%$ level indicating that the model was significant. The value of the Durbin-Watson statistic was closed to 2 implying that the model had no serial correlation problem. 
Table 7. ARDL long-run result

Dependent variable: $\left(\ln I N D_{\text {Out }}\right)$

\begin{tabular}{|l|r|r|r|}
\hline \multicolumn{1}{|c|}{ Variable } & \multicolumn{1}{c|}{ Coefficient } & t-statistics & \multicolumn{1}{c|}{ Probability } \\
\hline LNEXCHANGE_RATE & -0.137 & -0.819 & $0.021^{* *}$ \\
\hline LNEXPORT & 1.044 & 4.608 & $0.000^{*}$ \\
\hline LNIMPORT & -0.187 & -0.623 & $0.039^{* *}$ \\
\hline LNFDI & 0.055 & 0.414 & 0.683 \\
\hline LNTOP & 0.162 & 0.791 & $0.037^{* *}$ \\
\hline C & 2.952 & 0.877 & 0.000 \\
\hline R-squared & 0.656 & Durbin Watson Stat & 1.914 \\
\hline Adjusted R-Square & 0.875 & F-statistic (Prob) & 75.906 \\
& & & \\
\end{tabular}

** significant at $5 \%$, * significant at $1 \%$.

Source: Authors' computation (2019)

The result in Table 7 shows that an exchange rate and a value of imports are negative and statistically significant at 5\%. Hence a percentage increase in their values will result in a percentage decrease in industrial output in the short run in Nigeria. However, the value of export is positive and statistically significant at $1 \%$ implying a per cent increase in its value will result in a percentage increase in industrial output in Nigeria. Nevertheless, FDI and Trade Openness are insignificant for the period of investigation and as such do not inform the direction of an industrial output growth in Nigeria for the period of investigation.

The coefficient of the co-integration which gives the error correction term was also found to be negative and significant (Table 8). The Error Correction Term which denotes the speed of adjustment towards long-run equilibrium is 75.20 per cent. This explains that the whole system can achieve long-run equilibrium at a speed of $75.20 \%$. The adjusted R-square shows that the explanatory variables of the model explain $89.2 \%$ variation in the dependent variable (industry value added) in the short-run, while the remaining $10.8 \%$ was not captured endogenously. The value of the F-statistic was statistically significant at $1 \%$ level indicating that the model was significant. The value of the Durbin-Watson statistic was closed to 2 implying that the model had no serial correlation problem. 
Table 8. ARDL short-run relationship

Dependent variable: $\left(1 I N D_{\text {Out }}\right)$

\begin{tabular}{|l|r|r|r|}
\hline \multicolumn{1}{|c|}{ Variable } & Coefficient & t-statistics & \multicolumn{1}{c|}{ Probability } \\
\hline D(LNEXCHANGE_RATE) & -0.103 & -0.797 & $0.034^{* *}$ \\
\hline D(LNEXPORT) & 0.785 & 5.314 & $0.000^{*}$ \\
\hline D(LNIMPORT) & -0.141 & -0.637 & 0.530 \\
\hline D(LNFDI) & 0.041 & 0.413 & 0.683 \\
\hline D(LNTOP) & 0.122 & 0.772 & 0.448 \\
\hline CointEq(-1) & -0.752 & -6.699 & $0.000^{*}$ \\
\hline R-squared & 0.832 & Durbin Watson Stat & 1.893 \\
\hline Adjusted R-Square & 0.892 & F-statistic(Prob) & 53.552 \\
& & & $\left(0.000^{*}\right)$ \\
\hline
\end{tabular}

** significant at $5 \%, *$ significant at $1 \%$.

Source: Authors' computation (2019).

The short-run coefficient of exchange rate volatility is negatively signed and statistically significant at $5 \%$ level. The negative significant level of an exchange rate volatility shows that the fluctuations in an exchange rate over time in Nigeria have indirect relationship with an industrial output growth. This indicates that either appreciation or depreciation in an exchange rate significantly reduces an industrial output in Nigeria in the short-run.

\section{Granger causality test}

To model the direction of causality that exists between exchange rate volatility and industrial output growth in Nigeria, the functional relationship is specified below:

$$
\begin{aligned}
& I N D_{-} \text {OUTPUT } T_{t}=\sum_{i=1}^{m} \alpha_{i} I N D_{-} \text {OUTPUT } T_{t-i}+\sum_{j=1}^{n} \delta_{j} E X C_{-} R_{t-j}+\varepsilon_{1 t} \\
& \text { EXC_R } R_{t}=\sum_{i=1}^{m} \gamma_{i} I N D_{-} \text {OUTPUT } T_{t-i}+\sum_{j=1}^{n} \psi_{j} E X C_{-} R_{t-j}+\varepsilon_{2 t}
\end{aligned}
$$

where $E X C_{-} R$ is an exchange rate and IND_OUTPUT is an industry value added. $\varepsilon_{1 t}$ and $\varepsilon_{2 t}$ are the disturbances which are assumed to be orthogonal. Within this framework, there are four possible hypotheses. 
Case 1: Unidirectional causality from IND_OUTPUT to EXC_R. This is indicated if $\Sigma \alpha_{i} \neq 0$ and $\Sigma \delta_{j}=0$.

Case 2: Unidirectional causality from EX_R to IND_OUTPUT. This is indicated if $\Sigma \gamma_{i}=0$ and $\Sigma \Psi_{j} \neq 0$.

Case 3: Bilateral causality. This is indicated if $\Sigma \alpha_{i} \neq 0$ and $\Sigma \delta_{j} \neq 0$.

Case 4: No causality. This is indicated if $\Sigma \alpha_{i}=0$ and $\Sigma \delta_{j}=0$.

The result of the Granger Causality test from Table 9 reveals a bi-directional causality from exchange rate to industrial output growth and vice-versa. This implies that the rise in an exchange rate induces changes in an industrial output in Nigeria. However, a uni-directional causality was recorded from foreign direct investment to industrial output. The economic intuition is that more foreign inflow to the country (in the form of FDI) will induce growth in the industrial sector as more financial resources will be available to increase productive activities. Nevertheless, a unidirectional causality exists from a trade openness to an industrial output growth in Nigeria. The more the bilateral trade relations with other nations are, the better the prospects of improving the output of the industrial sector in Nigeria.

Table 9. Granger causality test result

\begin{tabular}{|c|c|c|c|}
\hline Null hypothesis & F-statistic & Prob. & Granger Causality \\
\hline $\begin{array}{l}\text { LNEXCHANGE_RATE does not Granger Cause } \\
\text { LNINDUSTRIAL_OUTPUT }\end{array}$ & 2.159 & 0.043 & \multirow[t]{2}{*}{$\begin{array}{l}\text { Bidirectional causality } \\
\text { EXC_R } \leftrightarrow \text { IND_OUT }\end{array}$} \\
\hline $\begin{array}{l}\text { LNINDUSTRIAL_OUTPUT does not Granger Cause } \\
\text { LNEXCHANGE_RATE }\end{array}$ & 0.003 & 0.004 & \\
\hline $\begin{array}{l}\text { LNEXPORT does not Granger Cause } \\
\text { LNINDUSTRIAL_OUTPUT }\end{array}$ & 0.447 & 0.509 & \multirow[t]{2}{*}{ No Causality } \\
\hline $\begin{array}{l}\text { LNINDUSTRIAL_OUTPUT does not Granger Cause } \\
\text { LNEXPORT }\end{array}$ & 2.950 & 0.097 & \\
\hline $\begin{array}{l}\text { LNIMPORT does not Granger Cause } \\
\text { LNINDUSTRIAL_OUTPUT }\end{array}$ & 1.608 & 0.216 & \multirow[t]{2}{*}{ No Causality } \\
\hline $\begin{array}{l}\text { LNINDUSTRIAL_OUTPUT does not Granger Cause } \\
\text { LNIMPORT }\end{array}$ & 2.967 & 0.096 & \\
\hline $\begin{array}{l}\text { LNFDI does not Granger Cause } \\
\text { LNINDUSTRIAL_OUTPUT }\end{array}$ & 2.972 & 0.006 & \multirow[t]{2}{*}{$\begin{array}{l}\text { Uni-directional causality } \\
\text { FDI } \rightarrow \text { IND_OUT }\end{array}$} \\
\hline $\begin{array}{l}\text { LNINDUSTRIAL_OUTPUT does not Granger Cause } \\
\text { LNFDI }\end{array}$ & 6.358 & 0.618 & \\
\hline $\begin{array}{l}\text { LNTOP does not Granger Cause } \\
\text { LNINDUSTRIAL_OUTPUT }\end{array}$ & 5.363 & 0.028 & \multirow[t]{2}{*}{$\begin{array}{l}\text { Uni-directional causality } \\
\text { TOP } \rightarrow \text { IND_OUT }\end{array}$} \\
\hline $\begin{array}{l}\text { LNINDUSTRIAL_OUTPUT does not Granger Cause } \\
\text { LNTOP }\end{array}$ & 0.338 & 0.566 & \\
\hline
\end{tabular}

Source: Authors' computation (2019). 


\section{Post estimation test}

The post estimation analysis is required to establish the robustness of the model estimated and also to confirm that the model estimated does not suffer from major econometric problems that could render the results emanating largely unfounded. In tandem with above, we proceed to estimate the post-model estimates of the serial correlation test (Breusch \& Godfrey, 2006) and the CUSUM structural stability test (Ploberger \& Kramer, 2006).

Table 10. Serial correlation test

\begin{tabular}{|l|c|l|c|}
\hline \multicolumn{3}{|l|}{ Breusch-Godfrey Serial Correlation LM Test } & \\
\hline F-statistic & 0.846 & Prob. F(3,25) & 0.443 \\
\hline Obs*R-squared & 2.237 & Prob. Chi-Square(3) & 0.327 \\
\hline
\end{tabular}

Source: Author's computation (2019).

Given the probability value of $32.68 \% t$, we fail to reject the null hypothesis and conclude that our model is free from serial correlation.

Figure 2 shows that the CUSUM line is within the critical bounds of 5 per cent level of significance which indicates that the model has structural stability.

Figure 2. CUSUM stability test

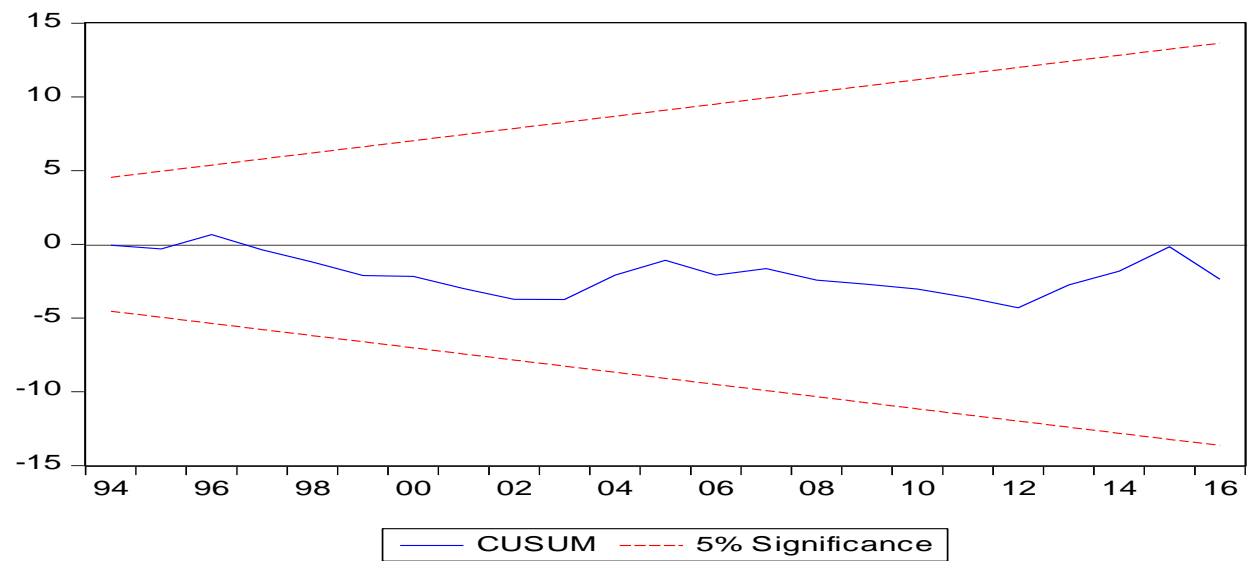

Source: Authors' computation (2019). 


\section{Discussion and conclusions}

The paper examines exchange rate volatility and industrial output in Nigeria from 1986 through 2017. In evaluating its objectives, the paper adopts the AutoRegressive and Distributed Lag (ARDL) model technique to co-integration to account for the short- and long-run dynamics of the model. The empirical result reveals that the exchange rate is volatile in Nigeria and as such sensitive to the performance of major sectors of the economy. Moreover, there exists a long-run relationship between an industry value added, an exchange rate, a value of import and export, and a trade openness in Nigerian. However, a long-run relationship exists between a foreign direct investment and an industry value added. Contrary to Ismaila (2016), Adeniran et al. (2014), who found a positive association between the regressed and the regressors, the result shows an adverse but significant effect of an exchange rate volatility on an industrial output growth in Nigeria. The result also reveals that in the short-run model, the interaction among an exchange rate, a value of imports, a value of export and an industrial output follows a priori expectations while that of a foreign direct investment and a trade openness does not follow a priori expectations. The result of the Granger causality reveals a bidirectional relationship between an industrial output and an exchange rate in Nigeria. As long as production grows, demand for the domestic product will drag exchange rate down and also permits industry to import technological know-how at a relatively fair price. It is therefore recommended that short-run policies should be tailored towards the expansion of a industrial sector growth to adjust for a deteriorating exchange rate needed for an expansion of and an improvement in the productivity of the industrial sector. The sensitive issues of money, security, and sustainable democratic governance should be prioritised in such a way that the lost investor's confidence can be regained.

This study examines the implications of an exchange rate volatility for an industrial output growth in Nigeria. It addresses the short fall in knowledge on the volatile exchange rate-industrial growth nexus in Nigeria by using accurate data and appropriate methodology to obtain findings that can redefine policy and research on the subject matter. The findings of this study by which it found volatility in an exchange rate to a significantly determine industrial production and also, a availability of foreign exchange increments arising from the various export drive to contribute tremendously to increase industrial output in Nigeria are in consonance with the findings of Ehinomen (2013); Fapetu \& Oloyede (2018); Ismaila (2016); Obadan (2006); Okafor et al. (2018) who found similar result. However, the findings of this study is in contrast with Barguellil, Ben-Salha, \& Zmami (2018); Franke (1991); Ogundipe et al. (2014); Oladipupo (2011) who 
found inverse relationship between an exchange rate fluctuations and a growth in their country specific analysis. Apparently, the uniqueness of our findings is rooted in being the first country study to estimate industrial output growth in Nigeria using conditional variance of exchange rate to generate sequence volatility. This is a better measure of exchange rate behaviour of an overly import dependent nation like Nigeria. It remains to be established if similar country analysis will produce similar results because of country specific variances and restrictions. The findings of this study will inform stakeholders, policy makers, financial institutions and the society at large about the magnitude and direction of exchange rate volatility for growth of the industrial sector in Nigeria. Particularly, it is required to boost or dent investor's confidence in the country. The study provides a paradigm shift for subsequent measurement of an exchange rate volatility measurement and its distinction from an exchange rate fluctuation when making an investment decision.

This study is limited to the facts obtainable from the study. Further research can be to examine the implication of an exchange rate volatility for growth in Sub-Sahara Africa countries because of their age-old characteristics of a lowincome generation, problems of financial instability that have a link with changes in the value of exchange rate over time.

\section{References}

Abdul-Mumuni, A. (2016). Exchange rate variability and manufacturing sector performance in Ghana: Evidence from cointegration analysis. Issues in Economics and Business, 2(1), 1-14. https://doi.org/10.5296/ieb.v2i1.9626

Addae, E., \& Ackah, I. (2017). Inflation dynamics in pre and post deregulation era in Ghana: Do petroleum prices have any influence? Retrieved from https://papers. ssrn.com/sol3/papers.cfm?abstract_id=2932340. https://doi.org/10.2139/ssrn.2932340

Adeniyi, O. A., Oyinlola, A., \& Omisakin, O. A. (2011). Oil price shocks and economic growth in Nigeria: Are thresholds important? OPEC Energy Review, 35(4), 308-333. https://doi.org/10.1111/j.1753-0237.2011.00192.x

Adekoya, O. M., \& Fagbohun, A. (2016). Currency devaluation and manufacturing output growth in Nigeria. Journal of Economics and Sustainable Development, 7(8), 207-218.

Adelowokan, O. A. (2012). Exchange rate pass-through in Nigeria: Dynamic evidence. European Journal of Humanities and Social Sciences, 16(1), 784-801.

Adeniran, J. O., Yusuf, S. A., \& Adeyemi, O. A. (2014). The impact of exchange rate fluctuation on the Nigerian economic growth: An empirical investigation. International Journal of Academic Research in Business and Social Sciences, 4(8), 224-233. https://doi.org/10.6007/ijarbss/v4-i8/1091 
Adeoye, B. W., \& Atanda, A. A. (2008). Exchange rate volatility in Nigeria : Consistency, persistency \& severity analyses. CBN Journal of Appllied Statistics, 2(2), 29-50.

Azid, T., Jamil, M., \& Kousar, A. (2005). Impact of exchange rate volatility on growth and economic performance: A case study of Pakistan, 1973-2003. The Pakistan Development Review, 44(4), 749-775.

Bahmani-Oskooee, M., \& Ratha, A. (2004). The J-curve: A literature review. Applied Economics, 36(13), 1377-1398. https://doi.org/10.1080/0003684042000201794

Barguellil, A., Ben-Salha, O., \& Zmami, M. (2018). Exchange rate volatility and economic growth. Journal of Economic Integration, 33(2), 1302-1336. https://doi.org/ 10.11130/jei.2018.33.2.1302

Baron, D. P. (1976). Fluctuating exchange rates and the pricing of exports. Economic Inquiry, 14(3), 425-438. https://doi.org/10.1111/j.1465-7295.1976.tb00430.x

Branson, W. H., \& Buiter, W. H. (1982). Monetary and fiscal policy with flexible exchange rates (NBER Working Paper, No. 901). Cambridge, MA: National Bureau of Economic Research.

Breusch, T. S., \& Godfrey, L. G. (2006). Data transformation tests. The Economic Journal, 96(Supplement 1), 47-58. https://doi.org/10.2307/2232969

Brodsky, D. A. (1984). Fixed versus flexible exchange rates and the measurement of exchange rate instability. Journal of International Economics, 16(3-4), 295-306. https://doi.org/10.1016/S0022-1996(84)80006-9

Calvo, G. A., \& Reinhart, C. M. (2002). Fear of floating. Quarterly Journal of Economics, 117(2), 379-408. https://doi.org/10.1162/003355302753650274

Coudert, V., Couharde, C., \& Mignon, V. (2011). Exchange rate volatility across financial crises. Journal of Banking and Finance, 35(11), 3010-3018. https://doi.org/ 10.1016/j.jbankfin.2011.04.003

Danmola, R. A. (2013). The impact of exchange rate volatility on the macro economic variables in Nigeria. European Scientific Journal, 9(7), 152-165. Retrieved from https://eujournal.org/index.php/esj/article/view/861

Devereux, M. B., \& Engel, C. (2002). Exchange rate pass-through, exchange rate volatility, and exchange rate disconnect. Journal of Monetary Economics, 49(5), 913-940. https://doi.org/10.1016/S0304-3932(02)00130-7

Edwards, S., \& Rigobon, R. (2009). Capital controls on inflows, exchange rate volatility and external vulnerability. Journal of International Economics, 78(2), 256-267. https://doi.org/10.1016/j.jinteco.2009.04.005

Ehinomen, D. C. (2013). Exchange rate management and the manufacturing sector performance in the Nigerian economy. IOSR Journal of Humanities and Social Science, 5(5), 1-12. https://doi.org/10.9790/0837-0550112

Enekwe, C. I., Ordu, M. M., \& Nwoha, C. (2013). Effect of exchange rate fluctuations on manufacturing sector in Nigeria, European Journal of Business and Management, 5(22), 67-73. 
Englama, A., Duke, O. O., Ogunleye, T. S., \& Isma'il, F. U. (2010). Oil prices and exchange rate volatility in Nigeria: An empirical investigation, Economic and Financial Review, 48(3), 31-48.

Fapetu, O., \& Oloyede, J. A. (2018). Effect of exchange rate volatility on economic growth in Nigeria (1986-2014). Afro-Asian J. of Finance and Accounting, 8(4), 404-412. https://doi.org/10.1504/aajfa.2018.10015519

Franke, G. (1991). Exchange rate volatility and international trading strategy. Journal of International Money and Finance, 10(2), 292-307. https://doi.org/10.1016/02615606(91)90041-H

Gray, P., \& Irwin, T. (2003). Exchange rate risk: Allocating exchange risk in private infrastructure projects (Viewpoint Note No. 266). World Bank, Retrieved from http://rru.worldbank.org/Documents/PublicPolicyJournal/266Gray-121203.pdf

Hamsal, M. (2006). The effect of paradoxical strategies on firm performance: an empirical study of Indonesian banking industry. Dissertation, Graduate School of Management, Faculty of Economics, University of Indonesian.

Ilechukwu, I. N., \& Nwokoye, E. S. (2015). Long run impact of exchange rate on Nigeria's industrial output. Journal of Economics and Finance, 6(5), 75-86. https:/doi.org/10.9790/5933-06527586

Ismaila, M. (2016). Exchange rate depreciation and Nigeria economic performance after structural adjustment programmes (Saps). NG-Journal of Social Development, 5(2), 122-132. https://doi.org/10.12816/0031175

Ito, T., Koibuchi, S., Sato, K., \& Shimizu, J. (2016). Exchange rate exposure and risk management: The case of Japanese exporting firms. Journal of the Japanese and International Economies, 41, 17-29. https://doi.org/10.1016/j.jjie.2016.05.001

Iyoha, M. A. (2005). Inflation and "openness" in less developed economies: A crosscountry analysis: Reply. Economic Development and Cultural Change, 26(1), 153155. https://doi.org/10.1086/451001

Jongbo, O. C. (2014). The impact of exchange rate fluctuation on industrial output in Nigeria. Journal of Policy and Development Studies, 9(1), 19-31.

Khondker, B. H., Bidisha, S. H., \& Razzaque, M. A. (2012). The exchange rate and growth: An empirical assessment on Bangladesh (Working Paper, No. 51). London: International Growth Centre (IGC).

Kiyota, K., \& Urata, S. (2004). Exchange rate, exchange rate volatility and foreign direct investment. World Economy, 27(10), 1501-1536. https://doi.org/10.1111/j.14679701.2004.00664.x

Klein, M. W., \& Shambaugh, J. C. (2008). The dynamics of exchange rate regimes: Fixes, floats, and flips. Journal of International Economics, 75(1), 70-92. https://doi.org/10.1016/j.jinteco.2007.10.003

Lawal, E. (2016). Effect of exchange rate fluctuations on manufacturing sector output in Nigeria. Journal of Research in Business and Management, 4(10), 32-39. 
MacDonald, R. (2007). Exchange rate economics: Theories and evidence. Exchange rate economics: Theories and evidence. London: Routledge. https://doi.org/10.4324 19780203380185

Mensah, M., Awunyo-Vitor, D., \& Asare-Menako, H. (2013). Exchange rate volatility and employment growth in Ghana's manufacturing sector. International Journal of Business and Social Science, 4(4), 225-232.

Muhammad, J., Streissle, E. W., \& Kunst, R. M. (2012). Exchange rate volatility and its impact on industrial production, before and after the introduction of common currency in Europe. International Journal of Economics and Financial Issues, 2(2), 85-109. Retrieved from https://www.scopus.com/inward/record.uri?eid=2-s2.084979802678\&partnerID=40\&md5=38843e1a673b7fc34b42103420bf273a

Mundell, R. A. (1963). Capital mobility and stabilization policy under fixed and flexible exchange rates. The Canadian Journal of Economics and Political Science, 29(4), 475-485. https:/doi.org/10.2307/139336

Narayan, P. K. (2005). The saving and investment nexus for China: Evidence from cointegration tests. Applied Economics, 37(17), 1979-1990 https://doi.org/10.1080/ 00036840500278103

Nugroho, A. (2012). Farmakologi. Pustaka pelajar. Yogyakarta, 13(3), 43-54

Nwosu, N. C. F. (2016). Impact of exchange rate volatility on economic growth in Nigeria, 1987-2014 (unpublished Ph.D Thesis). Department of Banking and Finance, University of Nigeria, Enugu.

Obadan, M. I. (2006). Globalization of finance and the challenge of national financial sector development. Journal of Asian Economics, 17(2), 316-332. https://doi.org/ 10.1016/j.asieco.2005.11.002

Obstfeld, M., \& Rogoff, K. (2011). The mirage of fixed exchange rates. Journal of Economic Perspectives, 9(4), 73-96. https://doi.org/10.1257/jep.9.4.73

Ogundipe, O. M., Ojeaga, P., \& Ogundipe, A. A. (2014). Oil price and exchange rate volatility in Nigeria. IOSR Journal of Economics and Finance, 5(4), 01-09. https:// doi.org/10.9790/5933-0540109

Okafor, T., Adegbite, E., \& Abiola, B. (2018). Exchange rate fluctuations, inflation and industrial output growth in Nigeria. International Journal of Supply Chain Management, 7(5), 118-128. Retrieved from https://www.scopus.com/inward/record. uri?eid=2-s2.0-85060874305\&partnerID=40\&md5=9c51bbc9b0694f55baefdaff7c ebb08d

Oladipupo, A. (2011). Impact of exchange rate on balance of payment in Nigeria. African Research Review, 5(4), 73-88. https://doi.org/10.4314/afrrev.v5i4.69260

Oseni, I. O. (2016). Exchange rate volatility and private consumption in Sub-Saharan African countries: A system-GMM dynamic panel analysis. Future Business Journal, 2(2), 103-115. https://doi.org/10.1016/j.fbj.2016.05.004

Pesaran, M. H., \& Shin, Y. (2012). An autoregressive distributed-lag modelling approach to cointegration analysis. In Econometrics and economic theory in the 20th century (pp. 371-413). Cambridge: Cambridge University Press. https://doi.org/10. 1017/cbo9781139052221.011 
Pesaran, M. H., Shin, Y., \& Smith, R. J. (2001). Bounds testing approaches to the analysis of level relationships. Journal of Applied Econometrics, 16(3), 289-326. https://doi.org/10.1002/jae.616

Ploberger, W., \& Kramer, W. (2006). The Cusum Test with Ols residuals. Econometrica, 60(2), 271-285. https://doi.org/10.2307/2951597

Sattar, R. R. \& ur Rehman, H. (2012). Effectiveness of exchange rate in Pakistan. Pakistan Journal of Commerce and Social Sciences, 6, 83-96.

Sensoy, A., \& Sobaci, C. (2014). Effects of volatility shocks on the dynamic linkages between exchange rate, interest rate and the stock market: The case of Turkey. Economic Modelling, 43, 448-457. https://doi.org/10.1016/j.econmod.2014.09.005

Solow, R. M. (1956). A contribution to the theory of economic growth. The Quarterly Journal of Economic, 70(1), 65-94. https://doi.org/10.2307/1884513

World Bank. (2010). World Development Indicators 2010. Washington, DC: The World Bank Group. https://doi.org/10.1596/978-0-8213-8232-5 